\title{
Experimental Verification of Single Phase Z Source Inverter for Photovoltaic Applications
}

\author{
V. Saravanan ${ }^{1}$, M. Aravindan ${ }^{2}$, V. Balaji ${ }^{3}$, M. Arumugam ${ }^{4}$ \\ ${ }^{1}$ Departement of Electrical and Electronics Engineering, Arunai Engineering College, Tiruvannamalai, Tamilnadu, India \\ ${ }^{2,3}$ Sri Chandrasekarendra Saraswathi Viswa Maha Vidyalaya (SCSVMV) University, Kancheepuram, Tamilnadu, India \\ ${ }^{2,3}$ MRT, Tamil Nadu Generation and Distribution Corporation Limited (TANGEDCO), Tiruvannamalai, Tamilnadu, \\ India \\ ${ }^{4}$ School of Electrical Engineering, Bahir Dar University, Ethiopia
}

\begin{tabular}{l} 
Article Info \\
\hline Article history: \\
Received Aug 01, 2017 \\
Revised Mar 08, 2018 \\
Accepted Mar 22, 2018 \\
\hline
\end{tabular}

Keyword:

Photovoltaic systems

Simple boost switching

Voltage boosting ability

Z Source inverter

Copyright () 2018 Institute of Advanced Engineering and Science. All rights reserved.

\begin{abstract}
A single phase $\mathrm{Z}$ source inverter is developed for better voltage boosting and inversion ability suited for photovoltaic power generation systems. The operation of the $\mathrm{Z}$ source inverter is described with relevant equations. Simple boost scheme is used for switching actions of the inverter. The performance of the inverter used for photovoltaic applications can be checked with simulation and experimental results, which prove that it has single-stage buck and boost capability and improved reliability.
\end{abstract}

\section{Corresponding Author:}

V. Saravanan,

Departement of Electrical and Electronics Engineering,

Arunai Engineering College,

Tiruvannamalai 606 603, Tamilnadu, India.

Email: vsaranaec@yahoo.co.in

\section{INTRODUCTION}

Photovoltaic power generation is becoming increasingly important, because it does not cause any fuel cost, when compared with other renewable energy resources. Photovoltaic (PV) systems need inverter to act as power conditioning unit between the source and load. These inverters have to handle various power quality issues due to PV source fluctuations, which impose stringent requirements for inverter topologies and their controls. [1] - [3]

Z Source Inverter (ZSI) employing an impedance network consisting of inductors and capacitors, coupled with inverter main circuit to the variable DC source, which overcomes the voltage fluctuation problems caused by inherent characteristics of the photovoltaic systems. ZSI features a wide range of voltage gain which is suitable for many applications. [4] - [7] ZSI can be used to realize both DC voltage boost and DC-AC inversion in a single stage, an economical approach for photovoltaic applications. [8, 9]

The work reported in this paper is organized as: Mathematical model of photovoltaic panel in section 2, Topology description of single phase $\mathrm{Z}$ source inverter along with control strategy in section 3. Simulation and experimental results are presented in section 4. Finally, conclusion is reported in section 5. 


\section{MATHEMATICAL MODEL OF PV PANEL}

PV panel converts the photo energy of sunlight to DC variable voltage. The amount of power extracted by a PV panel depends on its operating DC voltage. The maximum power point tracking (MPPT) is capable of extracting maximum power from the PV panel which is influenced by the solar insolation level and atmospheric temperature which are described in [10] - [13] A PV panel is formed by series-parallel interconnected identical PV cells. PV cell is represented by single diode model as shown in Fig. 1 in which a current source is kept in parallel with a diode and a series resistance.

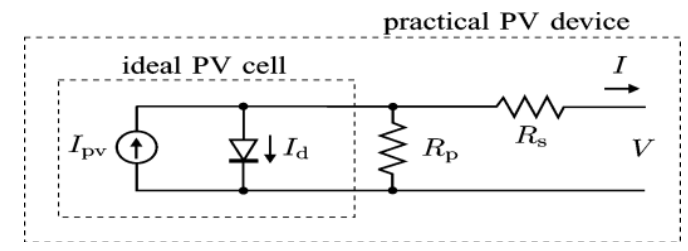

Figure 1. Single diode model of PV cell

The basic current equation of the PV cell is given by

$$
I=I_{p v}-I_{s a t}\left[\exp \left(\frac{q V}{A K T}\right)-1\right]
$$

where $I$ and $V$ are the output current and voltage of the PV cell, $\mathrm{I}_{\mathrm{pv}}$, is the light generated current, $\mathrm{I}_{\text {sat }}$ is the PV cell saturation current, $q$ is the charge of an electron, $\mathrm{K}$ is Boltzmann's constant, $\mathrm{A}$ is the ideality factor of the $\mathrm{p}-\mathrm{n}$ junction, and $\mathrm{T}$ is the PV cell temperature (degrees Kelvin).

From Eqn. (1),

$$
V=\frac{A K T}{q} \ln \left(\frac{I_{p v}+I_{s a t}-I}{I_{s a t}}\right)
$$

The output power of the PV cell, $\mathrm{P}$ is expressed as

$$
P=V\left\{I_{p v}-I_{s a t}\left[\exp \left(\frac{q V}{A K T}\right)-1\right]\right\}
$$

Simulations are carried out for mono crystalline PV panel of $30 \mathrm{Wp}$ as mentioned in Table 1 . Its performance is obtained for standard test conditions (i.e) solar insolation, $\mathrm{G}=1000 \mathrm{~W} / \mathrm{m}^{2}$ and temperature, $\mathrm{T}=25^{0} \mathrm{C}$. The diode ideality factor is chosen as 1.3. Various operating conditions of PV panel in terms of $\mathrm{V}_{\mathrm{OC}}$ and $\mathrm{I}_{\mathrm{SC}}$ are given as test data, loaded as a look up table in the simulation environment. Following results are obtained for the given conditions as mentioned in Table 2.

Table 1. Simulation parameters of $30 \mathrm{Wp} \mathrm{PV}$ panel

\begin{tabular}{cc}
\hline Parameters & Values \\
\hline Output Power, $\mathrm{P}_{\max }$ & $30 \mathrm{Wp}$ \\
Voltage at maximum power, $\mathrm{V}_{\mathrm{mp}}$ & $12 \mathrm{~V}$ \\
Current at maximum power, $\mathrm{I}_{\mathrm{mp}}$ & $2.50 \mathrm{~A}$ \\
Rated open circuit voltage, $\mathrm{V}_{\mathrm{OC}}$ & $16 \mathrm{~V}$ \\
Rated short circuit current, $\mathrm{I}_{\mathrm{SC}}$ & $3.0 \mathrm{~A}$ \\
Ideality factor, A & 1.3 \\
Temperature, $\mathrm{T}$ & $25^{\circ} \mathrm{C}$ \\
Solar Insolation, $\mathrm{G}$ & $1000 \mathrm{~W} / \mathrm{m}^{2}$ \\
\hline
\end{tabular}

Table 2. Simulation results for $30 \mathrm{Wp}$ PV panel

\begin{tabular}{ccc}
\hline Simulation results & \multicolumn{2}{c}{ Obtained values } \\
\hline Shunt resistance & Rp_min & $22.40 \Omega$ \\
& Rp_max & $44.21 \Omega$ \\
Series resistance & Rs_min & $0.37 \Omega$ \\
& Rs_max & $1.60 \Omega$ \\
\hline
\end{tabular}


From Table 2, it is observed that maximum power transfer from source to power conditioning system happens when the values of $R_{p}$ and $R_{s}$ should be high and low respectively. The values of $R_{p}$ and $R_{s} u$ sually not given by the manufacturers in the PV panel data sheet, which is needed for PV system designing. The I-V and P-V curves of 30Wp PV panel can be seen in Figure 2 and Figure 3 respectively.

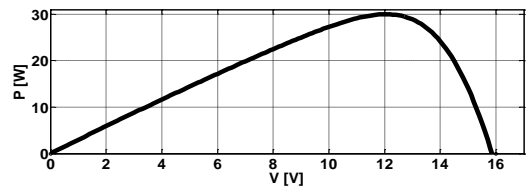

Figure 2. Simulated I - V Curve

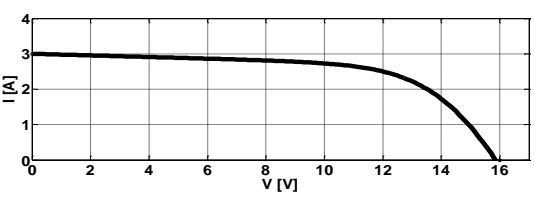

Figure 3. Simulated P - V Curve

The DC voltage obtained from the PV panel is fed to the input of ZSI and inverted AC output voltage can be obtained with better performance. The details of the same are explained and validated through simulations and experiments in the subsequent sections.

\section{CIRCUIT ANALYSIS OF SINGLE PHASE Z SOURCE INVERTER}

$\mathrm{Z}$ source inverter consists of two inductors $\left(\mathrm{L}_{1}\right.$ and $\left.\mathrm{L}_{2}\right)$ and two capacitors $\left(\mathrm{C}_{1}\right.$ and $\left.\mathrm{C}_{2}\right)$ connected in $\mathrm{X}$ shape to couple the inverter to dc voltage source obtained from photovoltaic systems. The operation of ZSI has two operating modes: non-shoot-through mode and shoot-through mode. In non-shoot-through mode, ZSI has six active vectors, when dc voltage is impressed across the three-phase load and two zero vectors when either the lower or upper three switching devices are conducting. In shoot through mode, load terminals get shorted, as both upper and lower switching devices of any phase leg of the inverter conducts. When the input voltage is high enough to produce desired output voltage, shoot-through zero state is not used and ZSI performs buck conversion, the same way as voltage-source inverter. When the input voltage is low, shoot through zero state is used to boost the voltage; therefore, ZSI performs as a buck-boost inverter.The voltage boosting capability of ZSI is due to energy transfer from capacitors to inductors during the shoot-through state. As the capacitors may be charged to higher voltages than the input source voltage, a diode is required to prevent discharging through the input source $[14,15]$ as shown in Figure 4.

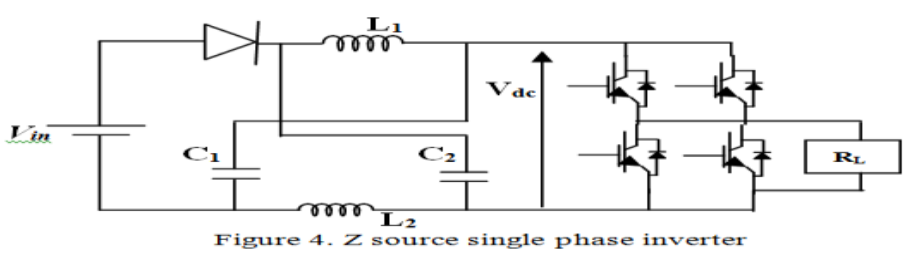

The average of dc link voltage across the inverter bridge is identical to capacitor voltage because the average of an inductor voltage becomes zero and capacitor voltage is dependent on the shoot through time.The gain expressions can be derived under different switching states [16] as follows:

Shoot $-\operatorname{Through}\left(S x=S x^{\prime}=\mathrm{ON}, x=A, B, \operatorname{orC} ; D=\mathrm{OFF}\right)$

$$
\begin{aligned}
& v_{L}=V_{c} ; v_{i}=0 ; v_{d}=2 V_{C} ; v_{D}=V_{d c}-2 V_{C} \\
& i_{L}=-i_{C} ; i_{i}=i_{L}-i_{C} ; i_{d c}=0
\end{aligned}
$$

Nonshoot $-\operatorname{Through}\left(S x \neq S x^{\prime}, x=A, B\right.$, or $\left.C ; D=\mathrm{ON}\right)$

$$
\begin{aligned}
& v_{L}=V_{d c}-V_{C} ; v_{i}=2 V_{C}-V_{d c} ; v_{D}=0 ; v_{d}=V_{d c} \\
& i_{d c}=i_{L}+i_{C} ; i_{i}=i_{L}-i_{C} ; i_{d c} \neq 0
\end{aligned}
$$

The state space averaging on (4) and (6) yields the 
Capacitor Voltage, $V_{C}=\frac{1-T_{\mathrm{o}} / T}{1-2 T_{\mathrm{o}} / T} V_{d c} \quad ;$ Peak dc Voltage, $\mathbb{\nabla}_{i}=\frac{V_{d c}}{1-2 T_{\mathrm{o}} / T}=B V_{d c}$

Peak ac output Voltage, 索 $=M \frac{\$_{t}}{2}=B\left(M \frac{V_{d c}}{2}\right)$

Here $T_{0} / T$ refers to the shoot through ratio, $M$ refers to the modulation index and $B$ refers to the boost factor.

The diode blocking voltage is given by

$$
v_{D}=-V_{d c} /\left(1-2 T_{0} / T\right)
$$

The inductor voltage is given as

$v_{L}=V_{d c} \frac{\left(1-T_{0} / T\right)}{\left(1-2 T_{0} / T\right)}$ during shoot through; $v_{L}=-V_{d c} \frac{\left(T_{0} / T\right)}{\left(1-2 T_{0} / T\right)}$ during non shoot through

Any modulation method as discussed in $[17,18]$ can be adopted to control the ZSI. Simple boosting switching scheme is employed for switching action of this ZSI due produce voltage boosting actions. Fig. 5 illustrate the Matlab/Simulink block model of simple boost switching scheme which is applied for the inverter.

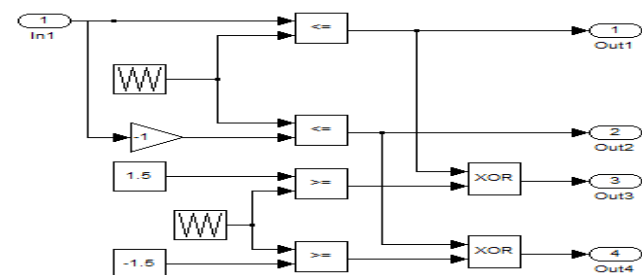

Figure 5. Switching sequence block diagram

\section{CIRCUIT ANALYSIS OF SINGLE PHASE Z SOURCE INVERETER}

\subsection{Simulation results}

The operation of ZSI are analyzed in steady state and its performances are validated using simulated results obtained in MATLAB/Simulink, where the solver is chosen as variable step discrete with step of 1.0 $\mu$ s with the following system parameters: $\mathrm{V}_{\mathrm{dc}}=12 \mathrm{~V} ; \mathrm{L}_{1}$ and $\mathrm{L}_{2}=1.5 \mathrm{mH} \quad \mathrm{C}_{1}$ and $\mathrm{C}_{2}=4700 \mu \mathrm{F}$ and the switching frequency, $\mathrm{f}_{\mathrm{s}}=20 \mathrm{kHz}$ and resistive load of $\mathrm{R}_{\mathrm{L}}=500 \Omega$. The MOSFET models whose internal resistance $R_{o n}=0.1 \Omega$ and snubber resistance $R_{s}=10^{5} \Omega$ are used for the switching devices. Figure 6 shows the capacitor voltage waveforms of capacitors $C_{1}$ and $C_{2}$ having the equal values of $25 \mathrm{~V}$ each. The output phase voltage of value $46 \mathrm{~V}$ is obtained through simulation across the load without filter as given in Figure 7. The obtained results verify that the ZSI produces better voltage boosting and inversion ability for the passive components used in the $\mathrm{Z}$ network.

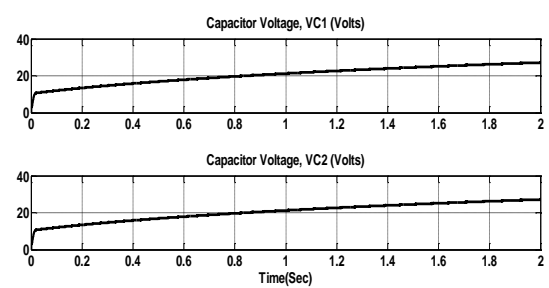

Figure 6. Simulated capacitor voltage waveforms $\left(\mathrm{C}_{1}\right.$ and $\mathrm{C}_{2}$ )

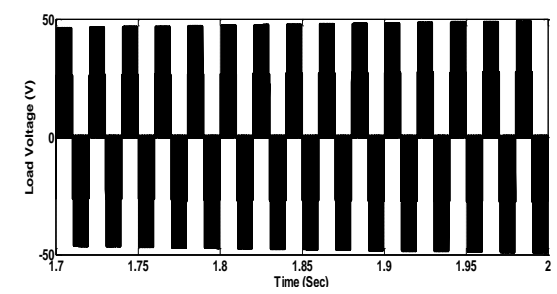

Figure 7. Simulated output voltage waveform 


\subsection{Experimental results}

To demonstrate the performance of ZSI, an experimental prototype was built in laboratory with the same parameters as used in the simulation. Fig. 8 shows the experimental setup of the proposed inverter setup which includes power MOSFETS, driver boards, impedance source networks, A/D conversion, serial communication and high performance FPGA unit. Simple boost PWM pulses are sent to the gate driver circuit. For the laboratory prototype, $12 \mathrm{~V}$ is given as input to the $\mathrm{Z}$ source network from PV panel. Power supply unit is employed separately from laboratory conditions for the operation of control/functional units of the inverter.The bridge rectifier IN4007 in the power supply unit is used to convert AC voltage into DC voltage. A LM 7805 regulator is used to fed a 5V supply to Field Programmable Gate Array (FPGA) processor and LM 7812 regulator regulates the inverter driver circuit operating voltages.

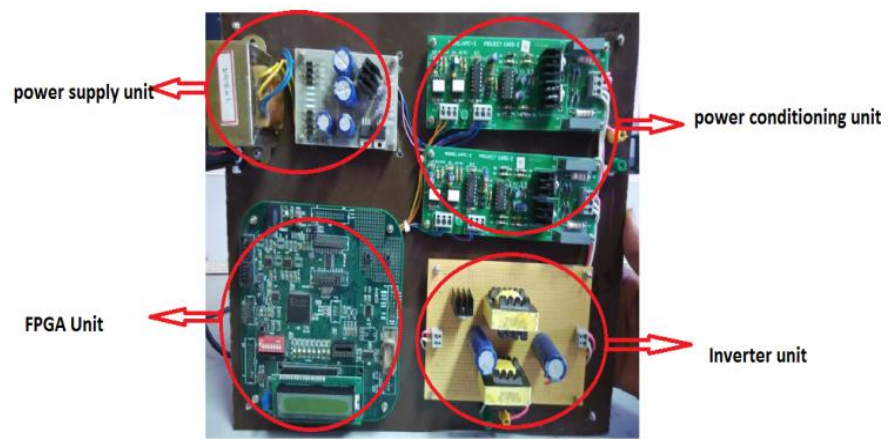

Figure 8 Experimental setup

SPARTAN 3E FPGA processor is used for generating PWM pulses and fed to MOSFET IRF 840 switches. The pulse width can be incremented or decremented based on the variation in the duty cycle given to the optocoupler 6N137. PWM pulses from the FPGA are fed to the optocoupler for isolation of control / power circuit to avoid the over current conditions. Optocoupler output signal is inverted from original PWM input signal by the use of NOT gate 4584.IR2110 is used to drive the MOSFET switches. High frequency diode BYQ28 is used and both the anode in them are shorted to split the current for reducing the inherent fault. Figure 9 and Figure 10 show the experimental results obtained from ZSI. For $12 \mathrm{~V}$ input DC voltage, Z network boosts the voltage level up to $46 \mathrm{~V}$ and made available at DC link voltage, which is to be fed to the inverter. After inverting action by ZSI, the peak to peak voltage across the load is obtained as $93 \mathrm{~V}$ for the resistive load of 500 ohms.

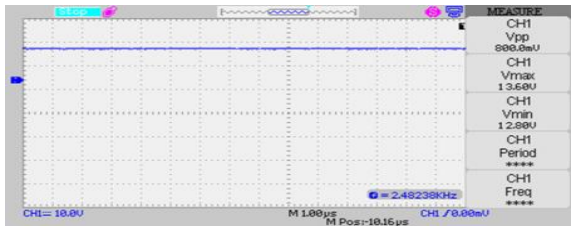

Figure 9. DC input voltage waveform

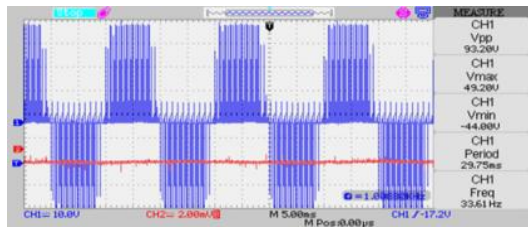

Figure 10. Peak to peak output voltage waveform

The ZSI inverts the boosted DC voltage and output AC voltage of $46.6 \mathrm{~V}$ is made available across the load, when it is measured without filter as shown in Fig. 10.These results correspond to the theoretical analysis and simulation results. The proposed ZSI acheives high boost inversion, upto the order of 4 . The proposed ZSI based PV power generation system can be scaled up for grid connected system, because it transfers the maximum power from the PV panel to grid without any additional MPPT algorithm.

\section{CONCLUSION}

The operation of $\mathrm{Z}$ source inverter is carried out in steady state condition to analyze boosting and inversion capability through simulation and experimental results. The obtained experimental results verify 
the analysis and discussion of proposed approach to the operation of ZSI for photovoltaic system. The proposed inverter can realize buck/boost, inversion and power conditioning in a single stage with improved reliability and it can be applied to the entire spectrum of power conversion. When ZSI connected to the grid supply, it requires to the address the concerns involving power regulation, harmonics reduction and power factor correction for various applications which are left to the readers.

\section{ACKNOWLEDGEMENTS}

This work was supported by Wind Energy Division, Ministry of New \& Renewable Energy, Government of India under grant (IFD Dy. No. 1429 dated 04/11/2016, Demand No. 61/69, Budget Head: 2810.00.104.04.05.31/35).

\section{REFERENCES}

[1] Lari Nousiainen, Joonas Puukko, AnssiM“aki, Tuomas Messo, Juha Huusari, Juha Jokipii, Jukka Viinam“aki, Diego Torres Lobera, Seppo Valkealahti, and Teuvo Suntio, "Photovoltaic Generator as an Input Source for Power Electronic Converters", IEEE Transactions on Power Electronics, vol. 28, pp. 3028-3038, 2013.

[2] Yaosuo Xue, Liuchen Chang, Søren Bækhøj Kjær, Josep Bordonau and Toshihisa Shimizu, "Topologies of Single Phase Inverters for Small Distributed Power Generators: An Overview", IEEE Transactions on Power Electronics, vol.19, pp. 1305 - 1314, 2004.

[3] Gunjan Varshney, D. S. Chauhan, M. P. Dave, "Evaluation of power quality issues in grid connected PV systems", International Journal of Electrical and Computer Engineering, vol. 6, pp. 1412-1420, 2016.

[4] Yam P. Siwakoti, Fang Zheng Peng, Frede Blaabjerg, Poh Chiang Loh, and Graham E. Town, "Impedance source networks for electric power conversion Part I: A topological review", IEEE Transactions on Power Electronics, vol. 30, pp.699-716, 2015.

[5] Deepak Kumar, Zakir Husain,"A comparative study of Z source inverter fed three phase IM drive with CSI and VSI fed IM”, International Journal of Power Electronics and Drive System, vol.3, pp. 259-270, 2013.

[6] S. Shanmugasundaram, "Solar based Z source inverter for high power application", Bulletin of Electrical Engineering and Informatics, vol. 6, pp. 343 -347, 2017.

[7] R. Malathi, M. Rathinakumar,"Comparison of sine and space vector modulated embedded Z source inverter fed three phase induction motor drive system", International Journal of Power Electronics and Drive System, vol.7,pp.1240-1251, 2016.

[8] Hanif, M., Basu, M. and Gaughan, K, "Understanding the operation of a Z source inverter for photovoltaic application with a design Example", IET Power Electronics, vol. 4, pp.278-287, 2011.

[9] C. Bharatiraja et.al,"Analysis, design and investigation on a new single phase switched quasi Z source inverter for photovoltaic application”, International Journal of Power Electronics and Drive System, vol. 8, pp. 853-860, 2017.

[10] Marcelo Gradella Villalva, Jonas Rafael Gazoli and Ernesto Ruppert Filho, "Comprehensive approach to modeling and simulation of photovoltaic arrays", IEEE Transactions on Power Electronics, vol.24, pp.1198-1208, 2009.

[11] Himanshu Sharma, Nitai Pal, Pradip Kumar Sadhu, "Modeling and simulation of off grid power generation system using photovoltaic", TELKOMNIKA Indonesian Journal of Electrical Engineering, vol. 13, pp. 418 - 424, 2015.

[12] Sobhan Dorahaki, "Evaluating the radiation and temperature effect on photovoltaic systems", Bulletin of Electrical Engineering and Informatics, vol. 4, pp. 1-6, 2015.

[13] M. Aravindan and V. Saravanan, "Performance analysis of single phase inverter for photovoltaic systems", International Journal of Applied Engineering Research, vol.10, pp. 27770 - 27774, 2015.

[14] Yu Tang, Shaojun Xie and Chaohua Zhang, " Single phase Z source inverter”, IEEE Transactions on Power Electronics, vol.26, pp.3869-3873, 2011.

[15] Dong Cao, Shuai Jiang, Xianhao Yu, and Fang Zheng Peng, "Low cost semi Z source inverter for single phase photovoltaic systems", IEEE Transactions on Power Electronics, vol. 26, pp.3514 - 3523, 2011.

[16] Poh Chiang Loh, Feng Gao and Frede Blaabjerg, "Embedded EZ source inverters", IEEE Transactions on Industry Applications, vol.46, pp. $256-267,2010$.

[17] Yam P. Siwakoti, F Z Peng, Frede Blaabjerg,P C Loh, Graham E. Town and Shuitao Yang, "Impedance source networks for electric power conversion Part II: Review of control and modulation techniques", IEEE Transactions on Power Electronics, vol. 30, pp.1887-1906, 2015.

[18] A. Sangari, R Umamaheswari "Analysis of impedance source inverter topologies for grid integration of PV inverters", International Journal of Power Electronics and Drive System, vol.6, pp.797-807, 2015. 